\title{
PENCEMARAN LINGKUNGAN AKIBAT PEMBUANGAN LIMBAH YANG DILAKUKAN OLEH PT. MEDCO DI KABUPATEN ACEH TIMUR MENURUT UNDANG-UNDANG NOMOR 32 TAHUN 2009 TENTANG PERLINDUNGAN DAN PENGELOLAAN LINGKUNGAN HIDUP
}

\author{
Radhali, Wahyu Ramadhani \\ Hukum Pidana, Fakultas Hukum, Universitas Sains Cut Nyak Dhien Langsa \\ Jln Perumnas No.45 Paya Bujok Seulemak Kota Langsa-Aceh, 23363 \\ radhali02111992@gmail.com,wahyu_ramadhani95@yahoo.com
}

\begin{abstract}
PT Medco recently violated Law Number 32 Year 2009 as happened in the East Aceh district by leaving a bad smell so that environmental pollution is ignored. The research objective is to determine the role of the government in tackling environmental pollution, to find out what obstacles the government faces regarding environmental pollution by PT Medco. This research method uses normative juridical and empirical juridical methods. The role of government in tackling environmental pollution is needed by the community so that companies can anticipate environmental pollution. The obstacles faced by the government related to environmental pollution carried out by PT Medco, namely in carrying out administrative, technological and educational prevention.
\end{abstract}

Keywords: Pollution, Environment, Waste Disposal

\begin{abstract}
Abstrak, PT Medco baru-baru ini telah melanggar Undang-Undang Nomor 32 Tahun 2009 seperti yang terjadi di kabupaten Aceh Timur dengan meninggalkan bau busuk sehingga pencemaran lingkungan terabaikan, maka dari itu peran pemerintah sagat penting dalam mengatasi ha tersebut untuk mengontrol agar pencemaran lingkungan dapat diatasi. Adapun tujuan penelitian untuk mengetahui peran pemerintah dalam menanggulangi pencemaran lingkungan, untuk mengetahui kendala apa saja yang dihadapi pemerintah terkait pencemaran lingkungan oleh PT Medco. Metode penelitian ini menggunakan metode yuridis normatif dan yuridis empiris. Peran pemerintah dalam menanggulangi pencemaran lingkungan sangat dibutuhkan oleh masyarakat agar dalam hal ini perusahaan yang berdiri ditengah-tengah masyarakat dapat mengantisipasi hal yang buruk terjadi karena pencemaran lingkungan dan tidak sewenang-wenang atas perbuatan mereka serta menjadi tolak ukur didalam menjaga pembuangan limbah yang berdampak pada masyarakat sekitar perusahaan akibat limbah. Kendala yang dihadapi oleh pemerintah terkait pencemaran lingkungan yang dilakukan oleh PT Medco yaitu dalam melakukan pencegahan secara administratif, teknologis dan edukatif.
\end{abstract}

Kata Kunci: Pencemaran, Lingkungan, Pembuangan Limbah. 


\section{Pendahuluan}

Provinsi Aceh merupakan daerah istimewa yang diberikan otonomi khusus oleh Negara Kesatuan Republik Indonesia dan telah banyak pula berdiri perusahaan baik itu BUMN maupun BUMD salah satu perusahaan yang berdiri di provinsi Aceh. Kabupaten aceh timur terdapat suatu perusahaan besar yang bernama PT Medco E\&P Malaka yang merupakan perusahaan minyak dan Gas pertama yang berhasil mengembangkan gas di Blok A, Kabupaten Aceh Timur pasca perdamaian Aceh.

Pada tahun 1999-2006 blok ini di kelola oleh Exxon Mobil dan Conoco Philips, dan pada April 2006, PT Medco E\&P Malak bersama partner (Premier \& Japex) mengakuisisasi kepemilikan saham Conoco Philips di Blok A hingga selesai kontrak pada September 2011. Pada Februari 2011, PT Medco E\&P Malaka mendapatkan perpanjangan kontrak 20 Tahun hingga September 2031. Pada saat ini komposisi kepemilikan Blok A, 85\% oleh PT Medco E\&P Malaka dan 15\% oleh PT Medco Daya Energi Nusantara.

Negara Indonesia juga mempunyai aturan hukum tentang permasalahan lingkungan hidup dalam mengawasi perusahaan yang ingin mengelola sumber daya alam, maka dalam hal perlindungan dan pengelolaan lingkungan hidup perlu memerhatikan pada Pasal 2 Undang-Undang Nomor 32 Tahun 2009 tentang Perlindungan dan pengelolaan lingkungan hidup menyebutkan bahwa Perlindungan dan pengelolaan lingkungan hidup dilaksanakan berdasarkan asas:

a.tanggung jawab negara;

b. kelestarian dan keberlanjutan;

c.keserasian dan keseimbangan;

d. keterpaduan;

e.manfaat;

f. kehati-hatian;

g. keadilan;

h. ekoregion;

i. keanekaragaman hayati;

j. pencemar membayar;

k. partisipatif;

1. kearifan lokal;

m. tata kelola pemerintahan yang baik; dan

n. otonomi daerah.

Selain itu pasal 3 Undang-Undang Nomor 32 Tahun 2009 tentang perlindungan dan pengelolaan lingkungan hidup memiliki tujuan sebagaimana dalam bunyi undangundang yaitu Perlindungan dan pengelolaan lingkungan hidup bertujuan:

a. melindungi wilayah Negara Kesatuan Republik Indonesia dari pencemaran dan/atau kerusakan lingkungan hidup;

b. menjamin keselamatan, kesehatan, dan kehidupan manusia;

c. menjamin kelangsungan kehidupan makhluk hidup dan kelestarian ekosistem;

d. menjaga kelestarian fungsi lingkungan hidup; 
e. mencapai keserasian, keselarasan, dan keseimbangan lingkungan hidup;

f. menjamin terpenuhinya keadilan generasi masa kini dan generasi masa depan;

g. menjamin pemenuhan dan perlindungan hak atas lingkungan hidup sebagai bagian dari hak asasi manusia;

h. mengendalikan pemanfaatan sumber daya alam secara bijaksana; i. mewujudkan pembangunan berkelanjutan; dan $\mathrm{j}$. mengantisipasi isu lingkungan global.

Adapun sanksi pada Undang-Undang Nomor 32 Tahun 2009 tentang pengelolaan dan lingkungan hidup dapat kita lihat pada Pasal 69 yang menyatakan bahwa :

(1) Setiap orang dilarang:

a. Melakukan pebuatan yang mengakibatakn pencemaran dan/atau perusakan lingkungan hidup;

b. Memasukkan B3 yang dilarang menurut peraturan perundang-undangan ke dalam wilayah Negara Kesatuan Republik Indonesia;

c. Memasukkan limbah yang berasal dari luar wilayah Negara Kesatuan Republik Indonesia ke media lingkungan hidup Negara kesatuan republik indonesia;

d. Memasukkan limbah B3 ke dalam wilayah Negara Kesatuan Republik Indonesia;

e. Membuang limbah ke media lingkungan hidup;

f. Membuang limbah B3 dan Limbah B3 ke media lingkungan hidup;

g. Melepaskan produk rekayasa genetic ke media lingkungan hidup yang bertentangan dengan peraturan perundang-undangan atau izin lingkungan;

h. Melakukan pembukaan lahan dengan cara membakar;

i. Menyusun amdal tanpa memiliki sertifikat kompetensi penyusun amdal; dan/atau

j. Memberikan informasi palsu, menyesatkan menghilangkan informasi, merusak informasi, atau memberikan keterangan yang tidak benar.

(2) Ketentuan sebagaimana dimaksud pada ayat (1) huruf $\mathrm{h}$ memperhatikan dengan sungguh-sungguh kearifan lokal di daerah masing-masing.

PT Medco baru-baru ini telah melanggar Undang-Undang Nomor 32 Tahun 2009 seperti yang terjadi di kabupaten Aceh Timur dengan meninggalkan bau busuk sehingga pencemaran lingkungan terabaikan. Jenis limbah yang dikaluarkan berupa cairan minyak dengan bahan kimia amoniak yang dalam hal ini disebut dengan Bahan Berbahaya dan Beracun (B3). Pemerintah sendiri dalam mengatasi limbah dari PT Medco yang berada dikawasan kabupaten Aceh Timur mengabaikan prinsip-prinsip yang seharusnya melindungi masyarakat dari limbah yang beracun sehingga membuat daerah sekitar perkampungan tercemar akan lingkungannya. ${ }^{1}$

Berdasarkan penelurusan dilapangan bahwa akibat dari limbah PT. Medco yang berada di kawasan Kabupaten Aceh Timur akibatnya air bersih menjadi susah, persawahan masyarakat mengalami kekeringan dan gagal panen, kesehatan masyarakat berakibat buruk serta masyarakat terganggu dengan udara yang bauk akibat dari limbah

1 https://aceh.tribunnews.com/2019/05/20/belum-ada-solusi-terkait-bau-busuk-wargaindramakmu-unjuk-rasa-ke-dprk-aceh-timur, diakses 13 Juni 2020 
yang dikeluarkan oleh PT. Medco sehingga masyarakat sekitar terganggu karena pembuangan limbah tersebut.

Berdasarkan latar belakang diatas maka timbul permasalahan yang harus dikaji yaitu:

1. Bagaimana peran pemerintah dalam menanggulangi pencemaran lingkungan ?

2. Apa saja kendala apa saja yang dihadapi pemerintah terkait pencemaran lingkungan oleh PT Medco ?

\section{Metode Penelitian}

Adapun dalam hal metode penelitian ini menggunakan metode yuridis normatif dan yuridis empiris, yuridis normatif merupakan suatu metode analisis yang menggunakan norma-norma hukum, seperti peraturan perundang-undangan yang beralaku untuk mengkaji suatu permasalahan. ${ }^{2}$ Sedangkan yuridis empiris adalah suatu penelitian dengan menggunakan data primer yang diperoleh langsung dari lapangan, hasil wawancara dengan informen dan responden. ${ }^{3}$

\section{Hasil Penelitian dan Pembahasan}

Berdasarkan permasalahan diatas maka disini akan dibahas kedalam hasil penelitian dan pembahasan sebagai berikut:

\section{Peran Pemerintah Dalam Menanggulangi Pencemaran Lingkungan}

Menurunnya kualitas lingkungan hidup tidak luput dari kesalahan suatu manusia. Manusia sering sekali lupa akan keterkaitannya dengan alam sehingga menyebabkan lingkungan dapat rusak dan hasilnya akan menuai bencana dan merebak terhadap masyarakat sekitar. Menurut Pasal 13 UUPPLH menyatakan bahwa pengendalian dari pencemaran dan/atau kerusakan lingkungan hidup dilaksanakan dalam rangka pelestarian fungsi dari lingkungan hidup. ${ }^{4}$

Dalam penjelasannya tentang pengendalian pencemaran lingkungan hidup adalah suatu pencemaran air, udara, laut serta kerusakan ekosistem dan kerusakan akibat perubahan iklim, kesuma itu merupakan hal yang harus diperhatikan oleh pemerintah. ${ }^{5}$ Sedangkan Pasal 53 ayat (2) menyatakan bahwa, penanggulangan pencemaran dan/atau kerusakan lingkungan hidup dilakukan dengan pemberian informasi peringatan pencemaran dan/atau kerusakan lingkungan hidup kepada masyarakat, pengisolasian

${ }^{2}$ Zaki Ulya, Dinamika Penerapan Hukum J inayat Sebagai Wujud Rekonstruksi Syari' at Islam di Aceh, Jurnal Rechts Vinding media pembinaan hukum nasional, Volume 5 Nomor 1, 2016, hlm. 138

${ }^{3}$ Suharsimi Arikunto, Prosedur Penelitian Suatu Pendekatan Praktek, (Jakarta: Rineka Cipta, 2020), hlm. 39

${ }^{4}$ Fajar Winarni dan Dinarjati, E.P, Peran Pemerintah Dalam Penanggulangan Pencemaran Air Tanah Oleh Bakteri E. Coli di Kota Yogyakarta, Jurnal Mimbar Hukum, Volume 25, Nomor 2, 2013, hlm. 221

${ }^{5}$ Aan Efendi, Hukum Lingkungan, (Bandung: PT Citra Adity Bakti, 2014), hlm. 13 
pencemaran dan/atau kerusakan lingkungan hidup, penghentian sumber pencemaran dan/atau kerusakan lingkungan hidup, atau suatu cara lain yang dapat disesuaikan dengan perkembangan ilmu pengetahuan dan teknologi. ${ }^{6}$

Kesemua hal diatas merupakan tanggungjawab dari pemerintah daerah demi menjaga lingkungan yang tercemar akibat ulah tangan, baik itu individu, kelompok maupun lainnya yang atas dasar pertimbangan tersebut harus diawasi oleh pemerintah daerah agar masyarakat sekitar yang tinggal dengan berdekatan perusahaan dapat hidup lebih layak.

Pemerintah dalam upaya mengatasi kerusakan lingkungan akibat dari pembuangan limbah sudah melakukan berbagai upaya agar perusahaan mematuhi segala bentuk aturan hukum yang dihasilkan oleh produk pemerintah, maka dalam menanggulangi permasalahan tersebut pemerintah daerah telah mensosialisasikan kepada perusahaan maupun masyarakat sehingga pemerintah daerah telah menjalankan fungsinya sebagai penjaga efektivitas dari berbagai aturan.

Bentuk pertanggungjawaban pemerintah terkait kerusakan lingkungan maupun limbah dari perusahaan dan sebagainya termuat dalam pasal 2 Undang-Undang Lingkungan Hidup, dimana dalam hal ini ada suatu asas lingkungan hidup adalah tanggungjawab negara. Maka menurut penjelasan Pasal 2 Huruf a Undang-Undang Lingkungan Hidup, yang dimaksud dengan tanggungjawab negara yaitu:

a.Negara menjamin pemanfaatan sumber daya alam akan memberikan manfaat yang sebesar-besarnya bagi kesejahteraan dan mutu hidup rakyat, baik generasi masa kini maupun generasi masa depan.

b. Negara menjamin hak warga negara atas lingkungan hidup yang baik dan sehat.

c.Negara mencegah dilakukannya kegiatan pemanfaatan sumber daya alam yang menimbulkan pencemaran dan/atau kerusakan lingkungan hidup.

Namun demikian peran pemerintah sendiri dalam hal ini masih kurang tegas dalam menjalankan roda pemerintahan kepada PT Medco dalam mengatasi permasalahanpermasalahan yang timbul akibat pencemaran lingkungan yang dilakukan oleh PT Medco. Seharusnya pemerintah daerah dapat melaporkan hal tersebut pada pemerintah provinsi maupun daerah dengan bekerjasama dengan badan pengelolaan lingkungan hidup untuk sama-sama memberikan laporan kepada pemerintah setingkat lebih tinggi diatasnya.

Pemerintah dalam hal pencegahan pencemaran lingkungan yang dilakukan oleh perusahaan industri wajib memerhatikan aturan sebagai mana yang terdapat dalam Pasal 74 Undang-Undang Nomor 32 Tahun 2009 tentang perlindungan dan pengelolaan lingkungan hidup yang menyatakan bahwa:

(1) Pejabat pengawas lingkungan hidup berwenang:

${ }^{6}$ Syafrudin, Sengketa Lingkungan dan Hak Gugat Masyarakat dan Pemerintah, (Surabaya: Airlangga University Press, 2013), hlm. 23 
a. Melakukan pemantauan;

b. Meminta keternagan;

c. Membuat salinan dari dokumen dan/atau membuat catatan yang diperlukan;

d. Memotret;

e. Membuat rekaman audio visual;

f. Mengambil sampel;

g. Memeriksa peralatan;

h. Memeriksa instalasi dan/atau alat transportasi; dan/atau

i. Menghentikan pelanggaran tertentu.

(2) Dalam melaksanakan tugasnya, pejabat pengawas lingkungan hidup dapat melakukan koordinasi dengan pejabat penyidik pegawai negeri sipil.

(3) Penanggung jawab usaha dan/atau kegiatan dilarang menghalangi pelaksanaan tugas pejabat pengawas lingkungan hidup pejabat pengawas lingkungan hidup.

Impelementasi dari peran pemerintah dalam menanggulangi pencemaran lingkungan diatas belum teratasi maksimal dikarenakan dalam hal ini masih banyak terjadi permasalahan tentang pencemaran lingkungan yang ada di kabupaten aceh timur tepatnya dengan masyarakat sekitar yang tinggal berdekatan dengan perusahaan setempat.

Pemerintah Kabupaten Aceh Timur seharusnya menjalankan amanah-amanah dari negara untuk melindungi masyarakat dari segala hal yang sifatnya dapat merugikan masyarakat, oleh karena itu perlu adanya pengawasan yang baik agar pihak perusahaan tidak dapat berbuat sesuatu yang telah diatur dalam Undang-Undang. Pemerintah daerah sendiri tidak serius dalam menangani hal yang sudah merugikan masyarakat, padahal masyarakat sudah pernah berujuk rasa atas pembuangan limbah yang di hasilkan oleh perusahaan.

Dalam hal menindaklanjuti laporan dari masyarakat maka dalam hal ini pemerintah harus sigap dalam bertindak agar apa yang di harapkan oleh masyarakat dapat segera diatasi oleh pemerintah daerah, namun oleh sebab itu peran pemerintah sangat penting dalam mengambil kebijakan untuk menyelamatkan masyarakat dari segala dampak yang dapat merugikan masyarakat atas limbah yang dikeluarkan oleh PT Medco.

Pencegahan pencemaran lingkungan hidup harus di imbangi dengan penanggulangan demi menjamin lingkungan yang bersih agar tidak tercemar seperti bau busuk udara yang ada di wilayah sekitaran perusahaan PT Medco Blok A, Kabupaten Aceh Timur. Pemerintah dalam hal ini harus melakukan suatu penerapan sanksi terhadap pelanggar lingkungan hidup yang dilakukan oleh perusahaan yang telah diatur dalam Undang-Undang Nomor 32 Tahun 2009 tentang perlindungan dan pengelolaan lingkungan hidup. 
Adapun sanksi yang diberikan oleh pemerintah terkait pencemaran lingkungan sebagai berikut:

1. Sanksi administratif

Sanksi administrasi yang diberikan pemerintah kepada perusahaan yang melakukan pencemaran lingkungan akibat dari perbuatannya maka dalam hal ini mempunyai fungsi instrumental, yaitu pencegahan dan penanggulangan perbuatan terlarang yang utamanya ditujukan terhadap perlindungan kepentingan bagi masyarakat sesuai dengan hukum yang dilanggar tersebut. ${ }^{7}$ Sanksi administrasi yaitu tidak membebaskan penanggungjawab usaha dan/atau kegiatan dari tanggungjawab pemulihan dan pidana. Dalam Pasal 76 aya (2) UUPPLH menyebutkan bahwa :
a. Teguran tertulis;
b. Paksaan pemerintah;
c. Pembekuan izin lingkungan; atau
d. Pencabutan izin lingkungan.

2. Sanksi perdata

Adapun sanksi perdatanya adalah berupa sanksi ganti rugi terhadap penduduk atau warga sekitar yang dirugikan akibat pencemaran yang dilakukan oleh suatu industry dan hal ini diatur dalam Pasal 87 ayat (1) Undang-Undang Nomor 32 Tahun 2009 tentang PPLH, bahwa:

"setiap penanggungjawab usaha dan/atau kegiatan yang melakukan perbuatan melanggar hukum berupa pencemaran dan/atau perusakan lingkungan hidup yang menimbulkan kerugian pada orang lain atau lingkungan hidup wajib membayar ganti rugi dan atau melakukan tindakan tertentu."

3. Sanksi pidana

Sanksi pidana yang dikenakan dalam hal ini baik itu disengaja ataupun tidak yang dalam hal ini telah melampaui batas pencemaran lingkungan, maka ketentuan ini diatur dalam Pasal 98 ayat (1) UUPPLH, yang menyebutkan:

"setiap orang yang dengan sengaja melakukan perbuatan yang mengakibatkan dilampaui baku mutu udara ambient, baku mutu air, baku mutu air laut, atau criteria baku kerusakan lingkungan hidup, dipidana dengan pidana penjara paling singkat 3 (tiga) tahun dan paling lama 10 (sepuluh) tahun dan denda paling sedikit Rp 3.000.000.000,00 (tiga miliar rupiah) dan paling banyak Rp. 10.000.000.000,00 (sepuluh miliar rupiah)."

Berdasarkan ketentuan diatas maka peran pemerintah dalam menanggulangi pencemaran lingkungan sangat dibutuhkan oleh masyarakat agar dalam hal ini

${ }^{7}$ Erwin, Muhamad, Hukum Lingkungan Dalam System Kebijaksanaan Pembangunan Lingkungan Hidup, (Bandung: Refika Aditama, 2008), hlm. 52 
perusahaan yang berdiri ditengah-tengah masyarakat dapat mengantisipasi hal yang buruk terjadi karena pencemaran lingkungan dan tidak sewenang-wenang atas perbuatan mereka serta menjadi tolak ukur didalam menjaga pembuangan limbah yang berdampak pada masyarakat sekitar perusahaan.

Namun dari sanksi-sanksi yang telah tertuang dalam Undang-Undang sikap Pemerintah daerah sama sekali tidak berbuat apa-apa atas kerusakan lingkungan yang telah dilakukan oleh PT Medco, padahal Undang-Undang jelas memberikan sanksi yang tegas kepada siapa saja pelaku kejahatan dari tindak pidana pencemaran lingkungan tersebut. Pemerintah aceh sendiri tidak menanggapi apa yang telah di beritakan dalam berbagai media, baik itu media cetak maupun media online atas perbuatan PT Medco yang telah merugikan masyarakat banyak akibat dari pembuangan limbah minyak dan gas.

\section{Kendala Yang Dihadapi Pemerintah Terkait Pencemaran Lingkungan Oleh PT Medco}

Pengendalian limbah perusahaan yang berakibatkan dapat tercemarnya lingkungan akibat industri kepada masyarakat setempat maka dalam hal ini pemerintah diwajibkan untuk mengawasi dan bertanggungjawab atas segala sesuatu yang berdampak pada pencemaran lingkungan. Dalam hal pencemaran lingkungan pemerintah wajib menguji kapasitas pengujian perusahaan seberapa mungkin kerusakan lingkungan yang dilakukan oleh setiap perusahaan yang berada di sekitarnya.

Lingkungan merupakan pokok yang penting untuk diselesaikan oleh pemerintah demi melindungi Negara dan bangsa, maka dalam menjaga kelestarian lingkungan pemerintah membuat aturan yang harus ditaati oleh setiap orang maupun kelompok dalam menjalankan di Negara Indonesia. ${ }^{8}$ Lingkungan tidak saja semata-mata untuk dijaga tetapi lingkungan merupakan jaminan hidup sehat yang harus dinikmati oleh setiap warga Negara yang berada dalam wilayahnya.

Tidak mudah untuk menjaga lingkungan sebagaimana yang telah dilakukan oleh pemerintah, dalam hal pencegahan akan terjadinya pencemaran lingkungan yang dibuat oleh perusahaan-perusahaan yang tidak bertanggungjawab maka pemerintah sendiri juga memiliki kendala-kendala yang dihadapinya seperti kejahatan perusahaan, oknum pemerintah dan lain sebagainya yang menjadi hambatan bagi pihak pemerintah untuk menegakkan hukum kepada setiap orang maupun kelompok yang melanggarnya. ${ }^{9}$

Pengendalian limbah oleh pemerintah terdapat beberapa kendala terkait kerusakan lingkungan yaitu terkait masalah pencegahan, penanggulangan, dan pemulihan, berikut kendala yang dihadapi oleh pemerintah terkait pencemaran lingkungan oleh PT Medco :

Pemeritah Kabupaten Aceh Timur dalam melakukan pencegahan terjadi berbagai kendala diantaranya secara administratif, teknologis dan edukatif.

8 Fajar Winarni dan Dinarjati Eka Puspitasari, Peran Pemerintah Dalam Penanggulangan Pencemaran Air Tanah Oleh Bakteri e. Coli di Kota Yogyakarta, MIMBAR HUKUM, Volume 25, Nomor 2, Juni 2013, hlm. 219 - 230

${ }^{9}$ Aan Efendi, Hukum Lingkungan, (Bandung: PT Citra Aditya Bakti, 2014), hlm. 23 
a. Secara administratif

Secara administratif pemerintah daerah mempunyai kendala secara administratif yaitu dalam hal pemberian peringatan atau teguran baik itu secara lisan maupun secara tertulis kepada PT Medco didalam pemenuhan protokol yang sudah ditentukan, peringatan teguran secara tertulis bahwa pemerintah telah memberikan peringatan secara tertulis namun dalam hal ini perusahan tidak mengindahkan atau merespon dengan baikoleh PT Medco sehingga terjadinya pencemaran lingkungan di area sekitar wilayah.

Pemerintah Daerah dalam memberikan kebijakan selalu terbentur dengan adanya oknum dari pemerintah yang mendukung kegiatan-kegiatan yang sudah disepakati antara pemerintah daerah dan perusahaan, hal ini membuat tidak berjalannya sanksi-sanksi yang diberikan kepada perusahaan.

Merujuk kepada pengaturan secara tertulis maka dapat kita lihat dalam Pasal 76 ayat (2) Undang-Undang Nomor 32 Tahun 2009, yang menerangkan sanksi administratif terdiri atas :

(a) Teguran tertulis;

(b) Paksaan pemerintah;

(c) Pembekuan izin lingkungan;atau

(d) Pencabutan izin lingkungan.

Dari uraian diatas maka teguran yang dilakukan oleh pemerintah tidak dilakukan dan tidak tegas terhadap perusahaan yang telah mencemarkan lingkungan dan dari penegakan sanksi administratif bersifat preventif sehingga tujuan untuk menegakkan peraturan perundang-undangan lingkungan tidak efektif. Teguran tertulis yang dilakukan oleh pemerintah seharusnya dapat direspon baik oleh perusahaan terkait atas adanya pengawasan oleh pemerintah namun dalam hal ini PT medco mengindahkan hal tersebut maka dari itu pemerintah yang dianggap dapat menjaga atau mengawasi lingkungan tidak berjalan secara efektif.

Sanksi administratif oleh pemerintah terutama fungsi dari instrumental yaitu pengendalian perbuatan terlarang di indhakan oleh perusahaan terkait. Sanksi administratif harus ditujukan kepada perlindungan kepentingan yang dijag oleh ketentuan yang dilanggar tersebut. ${ }^{10}$

Dalam hal pemberian sanksi oleh pemerintahpun dinilai tidak efektif dan tidak dijalankan sehingga terjadi kendala-kendala yang sedemikian rupa dan membebaskan pihak perusahaan dapat bertindak semaunya dalam hal pengaturan pembuangan limbah lingkungan hidup.

Kendala lain yang dialami pemerintah yaitu teguran secara tertulis sudah sering di sampaikan ke perusahaan seperti PT Medco, namun dalam hal ini

${ }^{10}$ Suparman Diraputra, Perumusan Harmonis Hukum Tentang Pengelolaan Sumber daya Alam, (Jakarta: Badan Pembinaan Hukum Nasional, 2001), hlm. 11 
perusahaan mengindahkan hal tersebut sehingga pemerintah telah melakukan diskusi dengan perusahaan agar dalam hal pembuangan limbah harus dikaji lagi dan tidak merugikan masyarakat pada umumnya.

Bila dilihat dalam Undang-Undang Nomor 32 Tahun 2009 tentang perlindungan dan pengelolaan lingkungan hidup pada Pasal 80 ayat (2) mengenai penegakan sanksi yaitu :

(a) Ancaman yang sangat serius bagi manusia dan lingkungan hidup;

(b) Dampak yang lebih besar dan lebih luas jika tidak segera dihentikan pencemaran dan/atau perusakannya; dan/atau

(c) Kerugian yang lebih besar bagi lingkungan hidup jika tidak segera dihentikan pencemaran dan/atau perusakannya.

\section{b. Secara Teknologis}

Kantor lingkungan hidup yang berada di kabupaten Aceh Timur mempunyai kendala dalam hal peralatan uji laboratorium terhadap limbha industry seperti perusahaan PT Medco yaitu seperti menguji sample limbah dari perusahaan, tidak adanya pegawai yang bisa memeriksa, meneliti dan menganalisis limbah, maka dalam hal ini sangat membahayakan dalam mengawasi perusakan lingkungan akibat limbah perusahaan yang selama ini dapat merugikan warga setempat.

Berdasarkan uraian diatas maka pengujian limbah perusahaan seharusnya dilakukan oleh kantor lingkungan hidup kabupaten aceh timur berdasarkan prosese-proses standard pengujian limbah, maka dalam hal ini proses pengolahan limbah harus dilakukan dengan cara:

1) Mendeteksi kapasitas instalasi air limbah;

2) Mendeteksi pencampuran air limbah dengan komponen air lain;

3) Kerusakan yang terjadi akibat limbah perusahaan;

4) Penggunaan alat ukur debit limbah (flow meter); dan

5) Pengambiln dta analisis pencemaran limbah lingkungan hasil self monitoring.

c. Secara edukatif

Kantor lingkungan hidup Kabupaten Aceh Timur terdapat kendala secara edukatif yang dalam hal penyuluhan kepada perusahaan maupun masyarakat yang tinggal disekitar perusahaan tidak berjalan secara efektif. Seharusnya pemerintah dalam hal penanggulangan yang dilakukan oleh dinas lingkungan hidup Kabupaten Aceh Timur harus memperhatikan sebagai berikut :

1) Meningkatkan kesadaran lingkungan diantaranya karyawan dan pengusaha perusahaan yang sedang beroperasi diwilayah sekitar; 
2) Memberikan penanganan atau penetapan criteria tentang kualitas dalam menjaga lingkungan;

3) Memberikan arahan kepada perusahaan mengenai produksi malalui kemajuan teknologi seperti memodifikasi alat produksi sedemikian rupa agar ramah lingkungan dan tidak menyebabkan terjadinya pembuangan limbah yang selama ini dapat merugikan warga sekitar.

Didalam menghadapi perusahaan yang menyebabkan pencemaran lingkungan oleh PT Medco maka pemerintah kabupaten aceh timur sendiri didalam menghadapi pencemaran lingkungan yang dilakukan oleh PT Medco banyak kendala yang dihadapi seperti adanya orang-orang pemerintah pusat maupun daerah yang melindungi perusahaan tersebut dari aturan hukum yang telah ditetapkan, kemudian PT medco dalam hal ini selalu mengabaikan prinsip-prinsip yang telah disepakati antara pihak pemerintah daerah maupun perusahaan.

Pemerintah seharusnya dalam mengakkan keadilan harus bijak dan tidak tumpang tindih didalam menegakkan keadilan, maka segala bentuk yang dapat merusak lingkungan seharusnya Pemerintah Aceh harus lebih serius dan mengawasi setiap perusahaan yang mendirikan akta pendirian dalam mengambil hasil alam, serta memerhatikan hak-hak dari masyarakat agar terlindungi dari perbuatan pembuangan limbah yang dapat merugikan masyarakat.

\section{Penutup}

Dari permasalahan diatas maka dalam hal ini dapat diberikan kesimpulan dari setiap permasalahan sebagai berikut :

1. Peran pemerintah dalam menanggulangi pencemaran lingkungan sangat dibutuhkan oleh masyarakat agar dalam hal ini perusahaan yang berdiri ditengah-tengah masyarakat dapat mengantisipasi hal yang buruk terjadi karena pencemaran lingkungan dan tidak sewenang-wenang atas perbuatan mereka serta menjadi tolak ukur didalam menjaga pembuangan limbah yang berdampak pada masyarakat sekitar perusahaan. Pemerintah harus menjadi control bagi perusahaan terhadap segala bentuk dampak yang ditimbulkan oleh PT Medco akibat dari pembuangan limbah yang berimbas langsung kepada masyarakat shingga peran pemerintah sendiri dapat menjadi pengayom serta memberikan perlindungan bagi masyarakat sekitar.

2. Kendala yang dihadapi oleh pemerintah terkait pencemaran lingkungan yang dilakukan oleh PT Medco yaitu terkait masalah pencegahan baik itu secara administratif, teknologis dan edukatif. Pemerintah dalam hal ini juga bertanggungjawab untuk mengawasi lingkungan yang dilakukan oleh PT Medco agar dalam hal ini PT Medco mempunyai tanggungjawab yang serius akibat dari pembuangan limbah yang berdampak langsung di lingkungan masyarakat sekitar. 


\section{Daftar Pustaka}

\section{A. Buku}

Aan Efendi, Hukum Lingkungan, PT Citra Adity Bakti, Bandung, 2014

Erwin, Muhamad, Hukum Lingkungan Dalam System Kebijaksanaan Pembangunan Lingkungan Hidup, Refika Aditama, Bandung, 2008, halaman 52

Fajar Winarni dan Dinarjati, E.P, Peran Pemerintah Dalam Penanggulangan Pencemaran Air Tanah Oleh Bakteri E. Coli di Kota Yogyakarta, Jurnal Mimbar Hukum, Volume 25, Nomor 2, 2013

Suharsimi Arikunto, Prosedur Penelitian Suatu Pendekatan Praktek, Rineka Cipta, Jakarta, 2020

Suparman Diraputra, Perumusan Harmonis Hukum Tentang Pengelolaan Sumber daya Alam, Badan Pembinaan Hukum Nasional, 2001

Syafrudin, Sengketa Lingkungan dan Hak Gugat Masyarakat dan Pemerintah, Airlangga University Press, Surabaya, 2013

\section{B. Artikel Jurnal}

Fajar Winarni dan Dinarjati, E.P, Peran Pemerintah Dalam Penanggulangan Pencemaran Air Tanah Oleh Bakteri E. Coli di Kota Yogyakarta, Jurnal Mimbar Hukum, Vol. 25, No. 2, Juni 2013

Zaki Ulya, Dinamika Penerapan Hukum Jinayat Sebagai Wujud Rekonstruksi Syari'at Islam di Aceh, Jurnal Rechts Vinding Media Pembinaan Hukum Nasional, Vol. 5 No. 1, April 2016

\section{Internet}

https://aceh.tribunnews.com/2019/05/20/belum-ada-solusi-terkait-bau-busuk-wargaindramakmu-unjuk-rasa-ke-dprk-aceh-timur, diakses 13 Juni 2020

\section{Peraturan Perundang-undangan}

Undang-Undang Nomor 32 Tahun 2009 tentang Perlindungan dan Pengelolaan Lingkungan Hidup (Lembaran Negara Republik Indonesia Tahun 2009 Nomor 140, Tambahan Lembaran Negara Republik Indonesia Nomor 5059) 